\title{
An Ethnography of Shipping as a Communication Practice Within the Fujoshi Community in Indonesia
}

\author{
Devie Rahmawati ${ }^{1}$, Wiratri Anindhita ${ }^{2}$, Decintya $^{3}$, Amelita Lusia ${ }^{1}$, Ngurah Rangga Wisesa ${ }^{1}$ \\ ${ }^{1}$ Vocational Education Program, Universitas Indonesia, Indonesia \\ ${ }^{2,3}$ Universitas Negeri Jakarta, Indonesia \\ *Email: deviers@ vokasi.ui.ac.id
}

\begin{abstract}
This essay is an ethnographic study of communication practices within the fujoshi community in Indonesia that analyses three main issues: how a women becomes a fujoshi, the practice of shipping as a communication phenomenon, and social stratification within the fujoshi community. Our analysis applies a qualitative ethnography approach. The results of our research yielded three conclusions. Firstly, a women becomes a fujoshi when she finds boys' love content interesting and is attracted to the visual representations in boys' love manga. Secondly, shipping is the practice of pairing two fictional male characters in a romantic relationship. Shipping fantasies are expressed in the form of fan art, fanfiction, and doujinshi (explicit manga made by fans). The third is the social stratification within the fujoshi community in which there are fujoshi whose are considered either upper or lower class. This research concludes that shipping as a communication phenomenon is not performed by an individual fujoshi but rather involves the fujoshi community as a whole. Through the practice of shipping, fujoshi develop their own distinctive, unique culture.
\end{abstract}

Keywords: ethnography of communication, community, fujoshi, shipping, boys' love

\section{Introduction}

In Indonesia, there is generally low acceptance of the LGBT community. However, despite these negative attitudes toward sexual minorities, there are a significant numbers of women who enjoy homosexual themes in films, television, manga, and anime. This community of individuals is referred to as fujoshi. Fujoshi is a Japanese term for women who actively read, create, buy, and sell boys' love comics. Boys' love, often abbreviated as BL, is a sub-genre of Japanese manga which features romantic relationships between men. Fujoshi individuals are neither gay nor lesbian, and the homosexual content in boys' love doesn't represent actual homosexuality in the real world. The genre of boys' love is also not limited to professionally produced films, TV series, manga, or anime, but also includes texts created by fans, commonly known as doujinshi and fanfiction (Strickland, 2006). In texts written by fans, male characters who are c known to not be gay are commonly placed in a homosexual fantasy by the fan-author. The practice of placing two characters in a fictional romantic relationship is called "shipping." The study of fujoshi in Indonesia has previously been discussed in the fields of Psychology and Japanese literature. However, there are no ethnographic studies examining the communication practices within the fujoshi community; and therefore, this study provides a necessary contribution to the scholarship concerning of boys' love manga and the women who read them.

\section{Research Problem}

This paper attempts an ethnographic study of the communication practice of shipping within the fujoshi community in Indonesia - a subject which has so far been neglected in the ethnography of communication.

\section{Purpose}

The aims of this study are the following:

1. To study the causes behind someone becoming a member of the fujoshi community

2. To study the practice of shipping within the fujoshi community

3. To study the components of communication comprising the practice of shipping

4. To study the terminology used during shipping practices

5. To study the competence of communication used by fujoshi when performing shipping activity 
6. To study social stratification within the fujoshi community.

\section{Literature Review}

\section{Ethnography of Communication}

Ethnography of communication is the analysis of communication patterns within a group or community. In this study, we aim hasten the acceptance of the communication style of this particular community by society. The work of ethnography consists of (a) identifying patterns of communication used by a group or community, (b) translating the types of communication used by the group or community, (c) determining when and where the members of the community perform said communication, (d) ascertain how communication patterns contribute to the formation of the community, (e) document the variety of codes used by the group or community (Littlejohn \& Foss, 2012, p. 460). In ethnographic research, communication is defined as the event or process of communication. Communication is the set of components used by individuals sharing the same language varieties, tone, setting and roles of interaction to discuss a certain topic. (Kuswarno, 2011, p. 41). According to Kuswarno (2011, pp. 42-43), identifying the components of communication is crucial to understanding how communication patterns are formed within the event of communication. The components of communication in ethnography are as follows:

- Genre or communicative events such as jokes, greetings, introductions, gossip, etc.

- Topic

- General and individual aims and functions

- Setting, including place, time, season, and other physical aspects (such as the size of the room, layout of the decorations, etc.)

- Participants, including age, gender, ethnicity, social status, relation to each other, and other relevant attributes

- The form of the messages as either non-vocal or verbal, as well as the nature of the codes (such as language and varieties)

- The content of the messages, including what has been communicated (with attention to connotative level and denotative references)

- The order of the behaviour or communication, including turnover and conversation phenomena

- Rules of interaction

- The norms of interpretation, including general knowledge, habit, culture, value, ethics and taboos that have to be followed, etc.

The other object of ethnographic study is competency within the communication process. Competency is the ability or inability to master a skill. This ability or inability will affect the shown communication. An individual may possess both knowledge of and skill at communication. Indeed, both can exist in a social community and will vary depending on each individual (Kuswarno, 2011, p. 43-44). The last subject of our research is language varieties. Kuswarno (2011, p. 45) was quoting Hymes, saying there will be variety of language codes and speech methods used in each society, or as communicative repertory. These principles of language are usually unconsciously applied during the process of socialization and enculturation.

\section{Shipping}

Within the subculture of fan fiction, shipping is commonly understood as placing two fictional characters in a romantic relationship. The creators of such fictions are women. The "ship" in "shipping" is derived from the "ship" in the world "relationship." Moreover, the active verb "to ship" refers to the act of creating a romantic storyline involving two characters. It is common for writers of fanfiction to fictionalize relationships between heterosexual couples as well as same-sex couples. Shipping which conforms to an official storyline is referred to as canon; those who engage in the practice of shipping are called "shippers." Unexpectedly, the potential candidates for shipping often extend beyond fictional characters to include celebrities (Kircher, 2015).

\section{Boys' Love and Fujoshi}

Fujoshi is the term for women who are fond of boys' love manga, also known as yaoi (Winduwati, 2015, pp. 5-6). The Japanese term yaoi is a portmanteau of the three Japanese phrases yamanashi (no climax), ochinasi (no ending), and iminashi (no meaning). Yaoi is characterized by homoerotic and homosexual romances between two or more young, attractive male characters. Outside of Japan, the term "boys' love" or the abbreviation "BL" 
is used more commonly than yaoi. Nurizky $(2012$, p. 3), while quoting Wim, states that the genre of boys' love first appeared in the form of a Japanese manga. According to Graffeo (2014, pp. 1-4), the Japanese term fujoshi means "rotten girl." Fujoshi is the term for women who ship two male characters in romantic context; the term for men who do the same is fudanshi. Fujoshi enjoy fantasizing over their favourite male characters by reading and collecting doujinshi, fanfiction, fan art, and other merchandise. However, their enjoyment of boys' love related content has o relation to their sexual orientation.

\section{Method}

This paper is a qualitative study which applies an ethnographic approach. Haris in Creswell (2014, p. 125) mentions that ethnography is a qualitative research method in which the researcher identifies and interprets patterns of value, behaviour, belief, and language within a certain group that possess a shared culture. Therefore, ethnography demands that a large sample of the target community be observed. Most ideally, a researcher embeds themselves as a member of the society to observe and learn from the interactions of the community members.

\section{Subjects}

The Subject of this study is the shipping practices of the fujoshi community. In Indonesia, the fujoshi community is not very visible, and is only observable on social media or at community events such as Japanese pop culture events. Most members use pseudonyms and do not make their personal information-such as name and occupation - public. When interacting, most individuals use English to conceal their nationality.

\section{Data Collection Method}

Kuswarno mentions five data collection methods in ethnography: introspection, participatory observation, deep interview, observation without participation, and document analysis (2011, pp. 48-59). In this study, we used four of the five methods, excluding observation without participation. Using the introspection method, we observed our own emotions while spending time within the fujoshi community and carrying out activities common to members of that group. We also attempted to determine whether these emotions were purely subjective, or whether the other fujoshi felt similar emotions. Later in the study, we compare the data collected with our own subjective experiences within the community. Using the participatory observational method, we observed the interactions between fujoshi on social media platforms such as Twitter, Facebook, and Tumblr from 2013 to 2016. Observations were also made of fujoshi gathering and interacting at certain popular events in Jakarta, such as the Anime Festival Asia (AFA), Comic Frontier (Comifuro), OTP-Con, and other independent small events, both spontaneous and organized. We once also attended a gathering of MakoRin shippers whose fandom revolves around the anime Free and a wedding parody put on by RivaEren shippers who enjoy the anime Attack on Titan. Deep interview methods were used while conducting direct observations of selected participants within the community. Interviews with seven individuals were conducted between and August 1-6, 2016

Meanwhile, we collected documents and newspaper articles and magazines related to the fujoshi community and the boys' love genre. We analysed typical patterns found in books or movies with or without boys' love storylines which motivated fujoshi to ship characters. We also clarify how the depiction of same-sex couples in boys' love fiction differs from the relationships of real LGBT people.

\section{Data Analysis Method}

We analyzed our data according to the three following aspects of data analysis outlined by Creswell (2014, pp. 275-277) and developed by Wolcott. They are description, analysis, and interpretation of the community. In this study, we studied our subject of analysis by collecting primary and secondary data through interviews, participatory observation, and document analysis. The collected data was then interpreted with the above mentioned method. 


\section{Results and Discussion}

\section{Reasons for Becoming Fujoshi}

\section{First time encountering boys' love.}

We discovered three reoccurring routes by which individuals become aware of boys' love content became interested in consuming it. The first route of discovery was accidently discovering boys' love content while looking for officially published content related to a particular character, such as illustrations or short stories. The second route of discovery was being introduced to boys' love content by someone who was already a fujoshi. The third route of discovery was when an individual fantasized about a romantic interaction between two male characters and enjoyed the thought. We also found out that each individual had a different reaction when discovering boys' love content for first time. Some people were attracted and interested immediately, whereas others were not interested at first but slowly came to enjoy boys' love content.

\section{An interesting aspect of becoming a fujoshi.}

Fujoshis in the community revealed that they became interested in boys' love content due mainly to the following factors:

- Boys' love content has more interesting and unique storylines compared to other anime

- The potential to make new friends in the community

- Male characters are visually appealing

- Cute and heart-warming interactions between gay couples

- The level of dedication displayed by fujoshi for their favourite couple, which is expressed through fan art, fan fiction, games, songs, short animations, and special events

- Gatherings between fujoshi

- Freedom to fantasize about a straight male character as a gay character

- Gaining new knowledge about sexual relations between same-sex couples

\section{The positive and negative side of fujoshi.}

Members of the fujoshi community themselves admit that there are both benefits and consequences to their hobby. The benefits of belonging to the fujoshi community are friendship, motivation to learn a foreign language, increased productivity in one's spare time, entertainment, open-minded thinking, and extra income from selling boys' love creations within the community. Negative aspects include social stigma and an overly stubborn insistence on all shipped couples be same-sex couples, resulting in disputes within fan sub-cultures.

\section{Shipping as a Communication Tool}

Often, the male characters that appear in shipping fantasies created by Fujoshi are not gay in the official published content from which they are derived from. Common examples are Sasuke and Naruto from Naruto and Captain America and Ironman from The Avengers. The motivation behind fujoshi enjoying boys' love storylines and the practice of shipping two male characters can be explained by the following points:

- $\quad$ Fujoshi's dislike of female characters.

- $\quad$ Shipping with female characters is boring because the hints are obvious; however, shipping between male characters is more challenging because hinting at their romantic attraction is more difficult and interesting

- The characterizations of the female characters are considered shallow and uninteresting. Most female characters in Japanese animations are depicted as weak, sloppy, and passive- traits preferred by males

- $\quad$ Forbidden same-sex relationships between men are considered more attractive

- $\quad$ Personal reasons deriving from the psychological trauma resulting from being rejected by men

Members of the fujoshi community usually fulfil their shipping desires by collecting merchandise, discussing, making artwork, and organizing events related to their ships. 


\section{Collecting merchandise.}

Fujoshi display their dedication by collecting merchandise of the respective characters they like. Such merchandise is categorized as official or unofficial. Unofficial merchandise usually features unique designs that would be impossible for official merchandise, such as illustrations of male characters in a romantic context. Thus, unofficial merchandise is more sought after and become objects central to the practice of shipping.

\section{Participating in shipping discussions.}

According to our observation, discussions mostly take place on social media platforms, such as Facebook, Twitter, and Tumblr. However, discussion also occurs when fujoshi meet each other in the real world. The topics discussed usually revolve around the motivation and reasoning behind why they shipped certain characters, an activity commonly referred to as "head canon."

\section{Making creative works based on ships.}

There are four categories of works that are commonly created by fujoshi. Fan art is illustrations featuring characters that can either be based on actual scenes from the series or completely fabricated. Male characters will generally be depicted as lovers and are often holding hands, hugging, kissing, or staring at each other. Fan fiction is a short story written by a fan. When a fujoshi writes fan fiction, the content is about a romance between two male characters. Doujinshi refers to short manga. The themes of doujinshi may vary, but generally they feature a romance or pornographic depiction of characters from a film, TV series, anime, game, or manga. Someone who authors a doujinshi is referred to as a doujinka. Finally is cosplay, or the act of wearing a costume and makeup to look like a character from an anime, game, manga, cartoon, movie, TV series, or other fictional work.

\section{Organizing a gathering.}

There are three types of events organized by fujoshi, commonly referred to as fujo-gath within the community. They are fan service gatherings, fandom gatherings, and ship gatherings. Common to all three events is the ability for fujoshi to interact offline through activities such as singing karaoke, discussing ship, drawing fan art together, and exchanging collections of doujinshi, fan art, and fan fiction. At fan-service gatherings, attending fujoshi belong to a variety of fandoms and ships. At fandom gatherings, all attendees belong to the same fandom but may enjoy different ships. At ship gatherings, fujoshi attendees all like one specific ship which serves as the theme of the gathering.

\section{Communication Tools in Shipping}

The ten ethnographic components of communication in the practice of shipping according to Kuswarno are described below.

\section{Genre of shipping.}

Shipping as a communicative event comprised of sharing head canon, discussing, and joking about ships. For fujoshi, shipping usually contains a head canon element which is based on their interpretation of the actual story. They receive inspiration from watching scenes and learning certain information regarding the characters or the couple they ship.

\section{Topic of shipping.}

The topic of communication is the main focus or theme of the conversation occurring during the practice of shipping. Such conversations are usually about the characters and related subjects. For example, communicative topics may be head canon discussion, ship discussion, how to actualize the idea of a ship, or fan fiction and doujinshi recommendations.

\section{Purpose of shipping.}

According to our data, the goal of shipping is personal entertainment. Shipping is an escape from the stress, pressure, and boredom of everyday life. Furthermore, fujoshi experience personal satisfaction when they are able to let their imaginations roam freely with disregard for the official story. 


\section{Setting of shipping}

When shipping alone, there are several necessary conditions for fujoshi to feel comfortable. Depending on location and time, each fujoshi has their own preferences. Some ship in their spare time, while some admit that they view fan fiction or doujinshi daily and think about boys' love stories or their favourite ship before sleeping. Some fujoshi don't mind doing such activities in public places, whereas some fujoshi prefer to enjoy their hobby alone. However, the secrecy of the hobby is a serious matter, with some individuals being vigilant to protect the internet histories of their smart phone and computer from the government and the wider society.

\section{Participants of shipping.}

Members of the fujoshi vary in age, ethnic background, and social status. Most fujoshi interact on social media and use a pseudonym or penname to conceal their real name. Within the shipping subculture, fujoshi are subcategorized into general fujoshi, fujoshi scanlators (one who scans and translates manga), fujoshi authors, and fujoshi informants. General fujoshi, or general audiences, show their dedication by collecting manga, novels, or merchandise without actually producing any creative work. Scanlator fujoshi assist with translating boys' love manga, novels, or doujinshi into the language of a target audience, such as from Japanese to English. Scanlator fujoshi are further divided into several smaller groups, such as the scanlator who prepares raw scans of manga or doujinshi, converting them to a digital format. The "cleaner" removes the dialogue from the manga so it can be replaced with an English translation. The "text provider" translates the dialogue into English. Both the cleaned version of the scans and the translations are handed over to the editor, who will combine them altogether. The result will be sent to a quality checker to be reviewed for both the quality and accuracy of the translation. Fujoshi authors produce works of boys' love content for shipping, be it original or interpretations of official content, such as works of fan fiction, fan art, or doujinshi. Fujoshi informants spread information regarding the ship to the fujoshi community. They are generally fluent in Japanese and up-to-date with news regarding the Japanese production team of a specific anime, game, or manga. Translations of news articles are shared to the fandom through social media platforms, such as Twitter or Tumblr.

\section{Types of messages in shipping.}

Messages in shipping, either verbal, verbal non-vocal, or non-verbal, are expressed through "fangirling" (Kuswarno, 2011, p. 43). Fangirling refers to the practice where fellow fangirls perform various actions in idolization of a specific object or subject, and the reaction upon seeing them. The reactions mostly consist of overflowing emotion and happiness.

\section{Verbal messages (oral).}

- Discussing ship with fellow fujoshi in face-to-face offline conversations

- Expressing feelings and opinions regarding a ship

- Swearing, using harsh words

- Showing gratitude and appreciation regarding a ship

\section{Verbal non-vocal messages (written).}

- Discussing ships with fellow fujoshi on social media

- Making creative works such as fan art, fan fiction, or doujinshis based on their ships

- Keyboard smashing, an act of pressing random capital letters on a keyboard or keypad to express their overflowing emotions

- Using emoticons to express facial expressions such as very happy, excited, or content

- Typing with capital letters without punctuation marks. This represents the process of fast information processing in the minds of fujoshi

- Spamming by posting a lot of comments, tweets, or status updates which are similar in content in a short amount of time

\section{Non-verbal messages.}

- Searching and collecting shipping merchandise

- Yelling, shouting, and screaming as an expression of amazement that can't be expressed through words 
- Smiling widely or laughing suddenly as a reaction to finding hints in boys' love content

- Doing uncontrollable gestures such as rolling on the bed, biting a pillow, hitting a desk, or smothering one's face in a pillow due to overflowing emotions

- Nudging a fellow fujoshi friend to help them catch a hint in boys' love content

\section{Messages in shipping.}

The content of messages in ethnographic research is what is communicated in a communicative event, whether on the connotative or denotative level (Kuswarno, 2011, p. 43). In shipping, the level of the connotative and denotative reference can be determined from the process of interpreting a normal fictional scene (denotative reference) as something that contains boys' love hints understandable to fujoshi (connotative level). Fujoshi decide to ship certain characters based on specific criteria, such as the closeness or chemistry between the male characters in the story or in the denotative reference. There are several scenes or denotative references that connote boys' love for fujoshi.

- Physical appearances of males are categorized into two types. Seme are tall, possess masculine features, have a low voice, and tend to be aggressive and dominant. Uke have a petite body, feminine features, a higher pitch voice, and tend to be passive and submissive.

- Affection shown by one character to another can be either verbal or nonverbal, such as giving attention, touching, staring, saying certain words, or other ambiguous gestures

- Situations where two male characters have been friends for a long period of time

- Situations where two male characters occupy oppositional positions, either as foes or rivals

- Situations where two male characters are in the same room

- Information about shipped male characters, such as personality traits and harmonies astrological signs

- When the number of male characters in a series exceeds that of female characters

Despite the representation of same-sex romances, the love stories of official fictional boys' love works should not be equated with representations of homosexually. They are heavily dramatized works of fiction and do not approximate reality.

Lillian Diaz-Przybyl, an editor at Tokyopop, a leading publisher of boys' love manga in the United States, stated that the interpretation of homosexuality in boys' love manga are often inaccurate. This is because these manga are drawn by female artists and are manifestations of women's fantasies about relationships between men.

\section{The order of shipping.}

This is the order of the shipping practice according to our data:

1) Watching or reading a fictional work

2) Identification of a favourite male character

3) Searching for another male character to be shipped with already identified character

4) Looking for hints or scenes with certain interactions that indicate potential chemistry between the male characters

5) Searching for fellow fujoshi with the same shipping interest

6) Looking for asupan, a term used by fujoshi to refer to fan art, fan fiction, and doujinshi which feature their ship

7) Making asupan if a fujoshi feels unsatisfied in regards to existing content involving their preferred ship

8) Interest peaks and they begin to get bored with their ship

9) Finding another series and starting the shipping process over again

Representation of the process is as follows: 


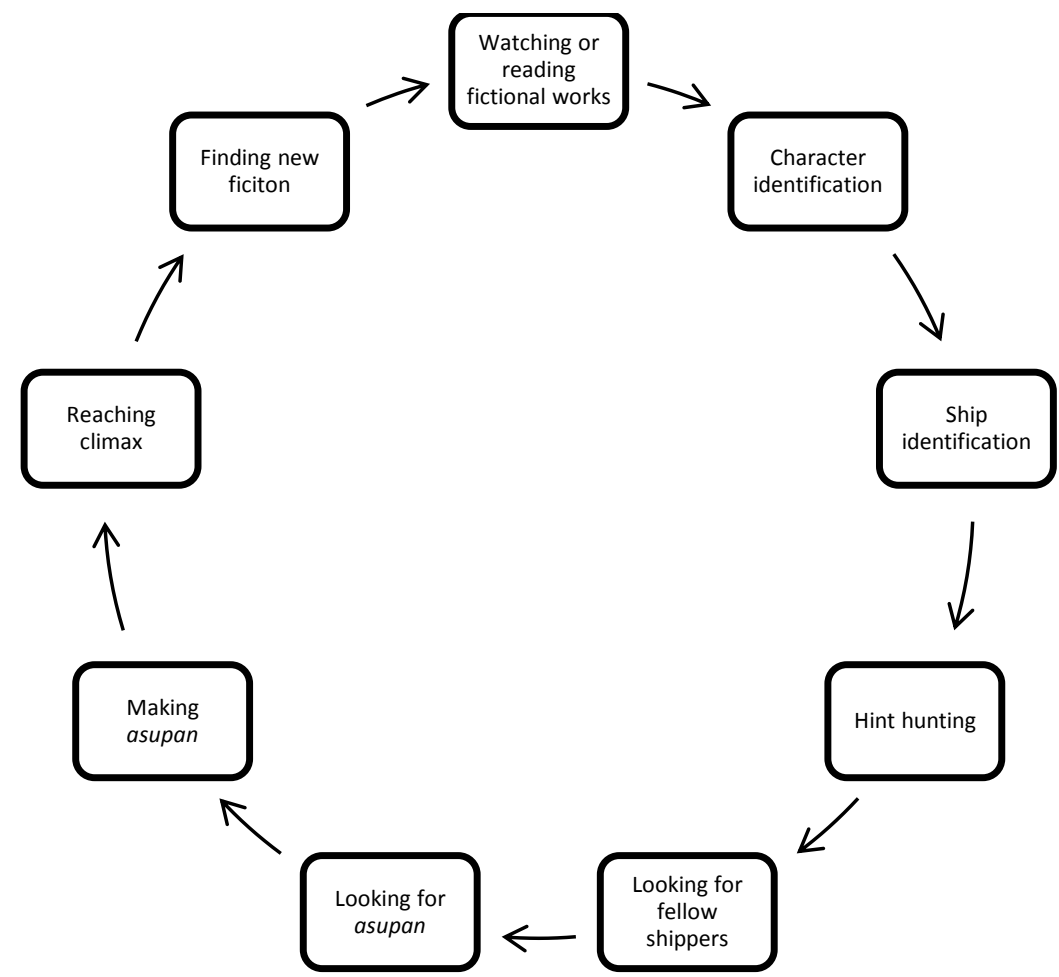

Figure 1. The process order of shipping

\section{Rules of interaction in shipping.}

The Rules of interaction in shipping are an unwritten agreement among members, according to which everyone is forbidden from criticising a ship regardless of their personal feelings. The rules are meant to avoid conflict between competitive fujosh $i$ who feel that their ships are superior. Other rules detail how to name and write a ship.

- When naming a ship, the name of a male character who acts as a seme or top shall be mentioned first, followed by the name of the uke or bottom. For example, in the ship of Naruto and Sasuke, Sasuke acts as a seme and Naruto as a uke; therefore, the ship is titled Sasuke-Naruto.

- Ships are also referred to by the construction seme name "X" uke name, with X standing for the romantic relationship between them. For example, the ship name for Sasuke-Naruto in literature is Sasuke X Naruto.

The name of the ship can also be written by combining the name of the two paired characters, following the same rule whereby seme is mentioned first followed by the uke. For example, the Sasuke X Naruto ship can also be combined as SasuNaru. Another example is Captain America X Iron Man from Avengers, with the ship itself referred to as "STony," with S derived from Captain America's real name, Steve Rogers, and Tony from Ironman's real name, Tony Stark.

\section{Norms of interpretation in shipping.}

Norms of interpretation involve common knowledge, habit, culture, value, beliefs, and taboo (Kuswarno, 2011, p. 43). In shipping, common knowledge includes international terms which are used similarly by fujoshi from different countries. In the fujoshi community in Indonesia, members advise each other as to when to reveal their hobby and when not to, due to the restrictions on discussing LGBT topics in Indonesia.

\section{The Linguistic Terms in Shipping}

There are unique language codes and terms used among members of the fujoshi community engaging in shipping. The terms serve as a description of what they are doing. Additionally, the terms also helps conceal the nature of their hobby from the general society. Members of the Fujoshi community learn these terms through a process of enculturation and socialization with other fujoshi community members. They gradually augment and 
add to the terminology according to the communicative patterns of the community. The terms used are as follows:

- Yaoi refers to the Japanese boys' love genre. Yaoi manga depict a romantic story between two males and contain relatively explicit sexual scenes. Fujoshi use this term as a polite version of gay.

- Shounen-a refers to yaoi without sexual scenes. Shounen-ai manga contain similar romantic scene between men but physical contact is limited to hugging and kissing.

- Bromance is a portmanteau combining the words "brotherly" and "romance" and refers to a close relationship between two male characters without a romantic component.

- Seme is a Japanese word for a male character who plays the dominant role in a gay relationship

- Uke is a Japanese word for a male character who plays the submissive role in in a gay relationship

- Seke is a Japanese word for a male character who is versatile and can act as both seme and uke.

- Hints are scenes in fictional stories that give away clues as to the potential compatibility of two male characters. For fujoshi, hints are ambiguous scenes that imply hidden meanings, such as feelings between two male characters. Often they are simply the imaginative creations of fujoshi.

- Fandom refers to a community of fans of a certain fictional work, such as a game, anime, manga, or film. Unlike fans clubs or fan bases, fandoms are not limited to a certain geographic area and are often internet based.

- Canon is a term used to refer to events that occurred in the official storyline of a certain fiction work. Canon excludes works by fans. It can be character development, or relationships between characters. Canon has the potential to destroy a ship, or in this context, their imaginative boys' love ship.

- Head canon refers to the analysis or hypothesis of what might happen behind the scenes of a fictional story, based on what is happening in the actual storyline.

- Plot bunny is a condition where fujoshi suddenly come up with multiple ideas or story plots for their fan fiction or doujinshi material. The term "bunny" is used because it suggest the qualities of agility and productivity, similar to ideas popping in and out of one's mind.

- OTP stands for One True Pairing and refers to a paring well-liked by fujoshi where the two characters are considered to be meant for each other.

- $\quad$ NOTP stands for Not One True Pairing and refers to a widely disliked pairing.

- Minor OTP and major OTP refer to, respectively, a ship that is rarely liked by other fujoshi in the community and a ship that is well-liked in the community

- A crack pairing is a pairing where it is difficult to imagine the characters together. Sometimes they don't even interact in the actual storyline. Such a pairing is usually meant for jokes by fujoshi. Crack pairings are categorized as a minor ship.

- Ship war refers to a conflict between different groups of fujoshi. In most cases, they think that their OTP is the best and tend to bash other ships without showing respect to other shippers.

- Asupan refers to anything that can satisfy a fujoshi's needs, such as hints, fan fiction, fan art, doujinshis, and ship discussion.

- Idol shopping is the activity of buying boys' love or shipping merchandises. The prices are often expensive and the amount spent is high, driving fujoshi to collect more. They serve no function and are simply collectibles. Hence, the term idol implies a contradiction with religion.

- Racun means poison and is a term used to refer to pre-order catalogues of boys' love merchandise. The term has a meaning similar to idol. It is referred to as poison because they are poisonous to one's financial situation, and fujoshi are helpless to resist their temptation

- Sunken ship refers to a condition where a boys' love ship is made impossible due to circumstances such as a character's death or marrying another character, usually female, in an official storyline.

- Titanic refers to a sunken ship that is popular. The most popular Titanic was when the Naruto series ended. A lot of fujoshi were shipping Sasuke and Naruto when Naruto married Hinata in the official story. This development immediately sunk the Sasuke-Naruto ship.

- Otome Road is a street in Tokyo where visitors can find everything related to anime targeted towards the female demographic, including boys' love content.

- Closet fujoshi, is a term for fujoshi who hide her interest from family and society. Usually, only several close fujoshi friends knows about their interest and even those in the community don't know their real identity. 


\section{Communication Competence in Shipping}

According to Kuswarno (2011, p. 43-44), competence or incompetence in regard to communication refers to the communication knowledge and skill of a social community or society. It can vary by individual, but the ability and inability (competence and incompetence) can result in culture shock or miscommunication. In the fujoshi community, the incompetence of a member is inferred from how they hide their hobby. Miscommunication often happens when fujoshi are careless with their hobby and identity. According to our data, such fujoshi disturb the peace and make non-fujoshi uneasy. Another incompetence can be observed when a fujoshi breaks the rules of shipping, which instruct that one must not bash another's ship despite a difference of opinion. A violation of this rule often leads to a ship war. Incompetence in communication can also be experience by new fujoshi. According to our data, it takes time and experience to learn all the language and terminology of the community. The speed of this process is influenced by how often fujoshi chat with other members of the community.

\section{Social Stratification within the Fujoshi Community}

Stratification within the fujoshi community occurs as result of differences in behaviour within the community. Some fujoshi are considered high-class and are labelled as elite fujoshi, fujoshi goddesses, fujoshi masters, or ship captains. The nickname ship captain is given due to their unrivalled dedication to the ship. There are also other reasons that influence to a fujoshi to be considered as high-class, such as:

- Possessing deep knowledge of the boys' love genre

- Displaying dedication towards the ship by either creating a high volume of creative work or spending considerable amounts of money

- Creating high-quality fan fiction, fan art, or doujinshi which can be consumed by other fujoshi

- Gaining one's own followers and fans

- Traveling to Japan to shop for boys' love merchandise

- Appearing calm and collected, unlike regular fujoshi

- Dressing fashionably

- Being a first generation fujoshi who pioneered boys' love forums in Indonesia. Younger fujoshi respect first-generation fans for persisting in the hobby despite persecution and the limited accessibility of boys' love content

Lower-class Fujoshi are often referred to as newbie fujoshi or ship crew. The term ship crew often appears alongside ship captain. While the ship captain is known for their dedication, ship crews tend to simply enjoy work created by the captain. The fujoshi in this category are mostly still new with minimum knowledge about boys' love and shipping. At the bottom of this hierarchy within the fukoshi community are those referred to as unstable fujoshi or fujoshit. Fujoshit is a portmanteau combining fujoshi and shit, and is used to mock unstable fujoshi who are often considered vulgar. They are often vocal about their hobby and therefore give a bad name to the entire community. The term is mostly used by people outside the community. A fujoshi can be considered fujoshit when they tend to do the following things:

- Shout openly in public revealing their interest in boys' love content. Most of time, they use the more general term gay instead of yaoi or boys' love so that non-fans understand. This behaviour is considered rude and disturbing to both fujoshi and non-fujoshi.

- Ignite a ship war between fujoshi by bashing other ships

Stratification conditions the interactions between fujoshi. When engaging with a higher class of fujoshi, individuals will augment their language. According to several sources, fujoshi will police their attitude and behaviour to avoid being considered fujoshit. Some interviewees admitted to feeling proud and motivated to create more creative work whenever a fujoshi of a higher class appreciate their work. However, when engaging with lower class fujoshi, some sources admitted to acting more responsible to prevent newbies from becoming fujoshit. Meanwhile, when engaging with a fujoshit, most fujoshi admit they try to avoid them. If they happen to know the person, they often try to chastise them for their attitude.

\section{Conclusion}

Our ethnographic study of communication in the fujoshi community focused primarily on shipping. Fujoshi tend to ship boys' love to the point of worshipping the ship. To realize their fantasies, fujoshi collect 
merchandise, create works, discuss, and organize gatherings or events in connection with their favourable ship. These activities are supported by various linguistic terms which influence the practice of shipping and inform the competence and incompetence of a fujoshi when shipping. All of these elements make up an ethnography of the fujoshi community. From a linguistic perspective, the variety and novelty of terms serve to conceal fujoshi from society. Fujoshi in Indonesia tend to hide their hobby from society due to intolerance of LGBT people in the country. When gathering on the internet, the majority of fujoshi use pseudonyms and seldom talk about personal information such as their addresses and personal life. Most of them strictly separate fujoshi related activities from their real lives. Personal information is given to close fujoshi friends only. An ethnography of communication in this community is unique both in the observed practices and the object of interest shared among community members. The fujoshi community has its own unique character that cannot be found in other communities, making it an interesting subject to be studied further.

We suggest further research on fujoshi and boys' love. The subject has not been discussed much in the communication field, leaving many aspects untouched, such as symbolic practices, personal communication, and group communication within the fujoshi community. We also recommend the fujoshi community to incorporate a social aspect into their events. We feel that fujoshi events are focused mostly on the fans and community entertainment, and do not attempt to invoke social sympathy or empathy. Moreover, fujoshi is identified with hedonism and consumerism. We feel this is unfortunate because despite giving pleasure to fellow fujoshi, they do not contribute positively to society.

\section{References}

Aarinfantasy's Yaoi Collection. (2016). Retrieved from http://aarinfantasy.com

Cha, K. (2005). Yaoi Manga: What Girls Like? Publishers Weekly. Retrieved from https://www.publishersweekly.com/pw/print/20050307/29621-yaoi-manga-what-girls-like.html

Creswell, J. W. (2014). Penelitian Kualitatif \& Desain Riset: Memilih Di Antara Lima Pendekatan, 3rd Edition. (A. L. Lazuardi, Trans.). Yogyakarta, ID: Cetakan Pelajar.

Indonesia Termasuk Paling Tidak Toleran Terhadap Homoseksualitas. (June 5, 2013), VOA Indonesia. Retrieved June 25, 2016.

Kircher, M. (2015). 'I ship them'- the strange concept that's changing the way people talk about relationships. Tech Insider. Retrieved from https://www.businessinsider.com/what-shipping-means-to-teens-2015-8.

Kriyantono, R. (2009). Teknik Praktis Riset Komunikasi. Jakarta, ID: Prenada Media Group.

Kuswarno, E. (2011). Etnografi Komunikasi: Pengantar Dan Contoh Penelitiannya. Bandung, ID: Widya Padjajaran.

Levitt, A. (2009). Girls Who Love Boys Who Love Boys: Inside the Midwest's first celebration of all things yaoi-where the screaming never stops. Riverfront Times. Retrieved from https://www.riverfronttimes.com/stlouis/girls-who-loveboys-who-love-boys-inside-the-midwests-first-celebration-of-all-things-yaoi-andmdash-where-the-screamingnever-stops/Content?oid=2482913

Littlejohn, S. W., \& Foss, K. A. (2012). Teori Komunikasi, 9th Edition. (M. Y.Hamdan, trans.). Jakarta, ID: Penerbit Salemba Humanika.

Meloeng, L. J. (2012). Metodologi Penelitian Kualitatif, Revised Edition. Bandung, ID: PT Remaja Rosdakarya.

Nurizky, F. (2012). Skripsi: Analisis Perubahan Perilaku Perempuan Penggemar Genre Boys'Love Melalui Forum Virtual di dalam Cyberspace, Universitas Indonesia (Unpublished).

Samovar, L. A, Porter, R. E., \& McDaniel, E.R. (2010). Komunikasi Lintas Budaya, 7th Edition. Translated by Indri Margaretha Sidabalok. Jakarta, ID: Penerbit Salemba Humanika.

Strickland, E. (2006). Drawn together. Village Voice. Retrieved from https://www.villagevoice.com/2006/10/31/drawntogether/

Sugiyono. (2012). Metode Penelitian Kuantitatif, Kualitatif, dan R\&D. Bandung (ID): Alfabeta.

Wenger, E., McDermott, R. A., \& Snyder, W. (2002). Cultivating Communities of Practice: A Guide to Managing Knowledge. Boston, US: Harvard Business School Press.

Why girls love boys love. (2006). Comics Beat. Retrieved August 20, 2016.

Winduwati, Septia. (2015). Journal: Fujoshi Remaja dan Kenikmatan Bermedia Yaoi (Studi Kasus Pada Remaja Putri Penggemar Fiksi Romantis Homoerotis Jepang). Universitas Tarumanegara. 